\title{
Structural Transformation to Take Off Economy in Developing Nations: Research on Theory and Practice in Vietnam
}

\author{
Nguyen Tan Phat ${ }^{1,2}$ \\ ${ }^{1}$ Department of Human resources, Vietnam National University Ho Chi Minh City, Vietnam \\ ${ }^{2}$ Faculty of Economics, University of Economics \& Law, Vietnam National University Ho Chi Minh City, Vietnam
}

Email address:

tanphat@vnuhcm.edu.vn

To cite this article:

Nguyen Tan Phat. Structural Transformation to Take Off Economy in Developing Nations: Research on Theory and Practice in Vietnam. Journal of World Economic Research. Vol. 4, No. 1, 2015, pp. 1-14. doi: 10.11648/j.jwer.20150401.11

\begin{abstract}
Structural transformation aims at shifting from undeveloped economy into developed one, yet maintains an increase in income and social welfare. A theoretical and empirical research in developed nations unveils that economic structure and its transformation play a decisive role for economic take-off. Economic structure is, however, an enormous issue; thus finding out the core or its starting point is regarded as the key deciding the impetus for economic take-off. On the basis of Rostow's theory, an empirical research from Hollis B. Chenery and successful industrialization in different nations, the author realizes that economic transformation generally derives from industrial production. On this foundation, the author initially discovers and suggests hypothesis of industrial-product structure as an efficient ruler of economic structure. It is used to verify Vietnam's growth in the period from 1986 to 2012 - a typical developing nation with growth through years but failure to take off. The research reveals that Vietnam's economic structure depends on a weak and less competitive industry, primarily on industries of food, beverage, resources exploitation and intensive laborers; hence take-off hand in hand with modification of economic structure, the core of which is industrial-product structure. Policy and measures on the scientific grounds coming from this theory suggest that a focus must be on heavy industry, consuming industry, supporting industry and processing industry, from which Vietnam compatibly benefits. Furthermore, effective role of every single economic sector must be determined to boost development of all industries. That is the best action for present and long term to take off economy.
\end{abstract}

Keywords: Structural Transformation, Economic Structure, Structure of Industrial Products, Vietnam's Economic Structure

\section{Introduction}

It is vital for developing countries to transform economic structure to take off, yet it is not simple and identical in all nations. It is the reason why there is a gap of growth among developing countries. Discovering the center of economic structure plays a virtually pivotal part toward structural shift, thus it drove the author to find out theory concerning structure of industrial product, considered as the heart of the economic structure. Accordingly, economic take-off will come true if there is a change in structure of industrial product. The author did a specific research on Vietnam- a nation with around 30-year growth but failure to take off with a target at proving the theory right.

The fact that discovery of structural modification resulting in development is a ground for developing regions stresses significance of changing production structure- a starting point for economic structural transformation. Hollis B. Chenery went through 20 to observe a group of 14 large nations and realized that take-off was performed well only when there was a change of manufacture in industrial sector as it has a positive effect on an increase in production scale, import value and income.

It has been proved that Vietnam economic growth throughout nearly 3 decades has failed to help economy take off, triggering worries the explanation of which is answering the question 'What is Vietnam supposed to do to take off the economy?' In recent years, Vietnamese economists and government have brought an urgent matter that economic restructuring is in the top in the to-do-list to improve model of growth.

Under the theory 'Structure of industrial products', the 
author researched Vietnam's economic structure in the phase between 1986 and 2012 to answer deficit in structural solidity such as long-lasting trade deficit, devaluation of Vietnamese dong, inflation, high bank interest taking place even on economic crisis, etc. The root reason is because primary industrial products have been food and beverage, exploitation of crude resources and intensive laborers whereas fundamental products such as energy, mechanism, car manufacture and supporting industry have been very restricted. That structure is uneasy for Vietnam to take off economy due to the consequences of economic institutions, commerce and investment, and the ineffective economic tool of State.

Thus, restructuring products should be carried out in 4 groups of main industries including heavy industry, supporting industry, consuming industry and processing industry as they are Vietnam's competitive strength. At the same time, a reform in economic institutions and commerce must be kept on. Position and role of each sector must be determined that sensible policy of investment and attraction could be made.

\section{Review Some Literatures}

\subsection{Economic Structure}

Economic structure is a rare terminology which seemingly fails to be shown officially in any current dictionary, even in economic one. However, if economy is considered as behavioral science belonging to social science, it is explanatory that the category of economic structure is inside social structure.

In the viewpoint of Toronto University, economic structure is the chief resource of income in a town or city, which is used to determine growth of city's economy.

Aren Van Schalkwyk (2011), working at University of Metropolian Nelson Manela, South Africa, defines that economic structure of the economy is an overall function of the entire different economic activities taking place inside political geographical borders of that region. [1]. Geoff Riley (2011), Eton College, England, states that economic structure is a terminology describing the balance change of productivity, trade, income, and a job picture from the various economic sectors, ranging from primitive type like agriculture, husbandry, fishery and coal exploitation, to second area like machinery and construction industry, to the third and fourth areas like tourism, banking and software industry. The transformation in economic structure is a natural characteristic in economic life as it contains challenges in the limits of determined factors existing in production. For instance, a change in production and jobs in a region could lead to issues of unemployed structure. [2]

Under that definition, economic structure is described as the general consisting of numerous framework and components making an economy. Economic structure comprises framework of branches (industry, agriculture and service) and framework of economic sectors; besides it reflects economic growth and per capita average income. Economic structure includes issues of structures of public finance and enterprise finance. It contains framework of trade, investment capital and even competitive competence.

According to Kuznets (1966), economic transformation is measured by the size of compositional change of aggregate demand, production, international trade, and use of capital and labor, which is regarded as a ruler of additional income of nations. Shift in economic structure is related to overall growth in some cases. The first case concerns growth of output which depends mostly on accumulation of material capital and workforce training; and growth rate answers the national scale of production responded from activities. The second involves demand. A raise in income only keeps the demand build-up when consumers aspire to use up their income for consumption of goods and service. The third, the ability of balancing the overall supply and demand for personal goods is maintained the effect by the large rate and composition of international trade.

Economist Hollis B. Chenery in the book 'Industrialization and Growth' indicated the compatible research among large nations in the process of structural transformation to take off. The most pervasive transformation of structure is industrial production.

Comparable researches at various rates of income reveal some joint characteristics of the evolution. One of the most pervasive factors is the modification of production structure, in which growth rate in industrial sector is more rapid than agricultural sector. There is a tight connection that industrial increase changes structure of overall demand, international commerce and workforce's careers. The internal changes of using economic resources which are under the enormous effect from government's policy constitute the heart of development strategy.

Thus, economic structure is a vast issue containing framework of economy, economic components and operations of the economy. In other words, they are external manifesto of economic structure.

\subsection{Economic Restructuring}

Under micro analysis, economic restructuring is restructuring an enterprise or an economic corporation with the following viewpoints.

Restructuring is reorganizing or rearranging enterprises to create a better state for them to perform the set targets. [3]

Company restructuring is the period of joint management concerning activities such as reorganizing a company's structure in the connection with legal matters, ownership, ways of operation and other structures with an aim at making the company better organized and managed due to its present demand. Other reasons for restructuring include modification of ownership or its structure, demerger or response to crisis or big changes in business such as bankruptcy, reorganization or buy-out. Restructuring can be described as restructuring corporations, debt and finance. [4]

Under macro consideration, economic restructuring is a large-scale alteration of an economy's activities in relation to 
many disciplines. There are some viewpoints as followed

Economic restructuring is a process of reorganizing an economy, producing changes of sectors or structure of an economy.

According to Hassen (1990), economic restructuring is about a phenomenon involving shift from production economy to service sector in western nations, affecting population including income distribution, employment, and social structure; the organizational arrangement embraces the development of a joint complex area, specialized production service, capital mobilizing, non-traditional economy, nonstandard jobs and original costs for work; and geographical arrangement includes the rise in cities throughout the world, space deviations, and the distinction of growth in big cities.

It is concluded that economic restructuring is a process of reorganizing or rearranging economic operations with a target on changing the current structure gearing toward a new, better and more efficient structure. Restructuring, under the micro level, is restructuring enterprises, but restructuring economy under the macro aspect.

\section{Hypothesis of Industrial Products Structure - An Instrument to Measure Economic Structure}

Rostow's take-off theory mentioned 3 factors to take off including (1) high capital accumulation, (2) key disciplines in which industry is the effective and motive force, and (3) stable socio-political institution. In the scientific abstract, the author temporarily excludes the first and the third factors, but the second is used for the research. Though there are numerous decisive disciplines, only industry is the single concentration; and a more concrete access chosen is industrial products.

The elimination of the 2 factors on the basis of scientific abstract is because the author recognizes that the majority of nations with the period of high and stable growth all reflect this state, but whether they achieve success in take-off is another matter. In addition, option to access industrial products is due to the fact that virtually nations with longterm growth possess key industries concerning strength of natural resources and political geography but whether industry is the motive force or not is a different matter. The models of classic industrialization in England, Soviet Union, or new industrial economies NIES, or developed nations in northeastern Asia like Japan all started with industrial products. That is so obvious that no proof is needed.

Thus, in the author's estimation, economic structure most crucially begins from structure of industrial products and the starting line for successful take-off must commence from the structural transformation of industrial products.

Definition: Structure of industrial products reflects derivation of all factors which constitute the product; the proportion of these factors to the value added up in comparison with the original total value of production factors.

\section{Typical Criteria Of industrial-product structure}

First, derivation of factors which constitute the product

It demonstrates the internal force of an economy and the capability of supplying resources of the economy to manufacture including material and supporting industry, etc. from which the real ability of the economy and its independence are exposed and perceived.

Second, proportion of factors which compose of the product

The proportion indicates the contribution regarding technical engineering, labor and capital, etc. in making products. It also reflects capability of an economy in the ways the products are made such as intensive-laborer, intensive-capital or intensive-engineering technology. The analysis of that proportion of production enterprises states in which stage of the evolution the economy is operating exportation of its available strength. (i) If they are products with a high rate of crude home material and intensive labor in agriculture like rice, coffee, pepper and seafood or garment, leather shoes, wooden products or crude oil which are regarded as available powers combined with simple exploitation and low value, it reflects the pre-takeoff of the economy. (ii) On the contrary, if the products rely on a high level of engineering, intelligence and massive capital, it shows growth and capability of competiveness of that economy, hence take-off stage.

Third, value added up

This value indicates the perspective of manufacturers to opt production discipline, level of engineering technology and efficiency in using resources. The structure following this direction will create an economy with high competiveness of product, technological breakthrough and especially with high values. That is the structure of particular parts in large nations and in countries with high economic development. Adherence to this path ensures to generate the initiative in competitiveness and enhances the value of an economy. This is a criterion to estimate the economic structure in the long-term tendency displaying the real strength of the economy and enterprises' competitiveness. The industrial-product structure itself and its shift sufficiently reflects the framework of an economy.[5]

\section{Data \& Analytical Method of Vietnam's Economic Structure}

The data analyzed mainly come from secondary figures of Vietnam's statistics directory in the stage between 1986 and 2012, which include figures of economic growth, per capita average income, structure of economic industries, structure of investment, public finance, public debt, ODA fund, interest rate of commercial banks, inflation rate, currency exchange, competitive competence of the nation.

Methodology: The approach of the researched issue in this article used is method of scientific abstract to identify primary factors with decisive effects on the economic and industrial-product structures. 
Method of data analysis is descriptive statistics, charts, tables and figures to show changes of statistical data and compositional ratio of those data, hence estimation, conclusion on economic structure and its state.

\section{Analysis of Vietnam's Economic Structure in the Phase between 1986 and 2012}

The Vietnam's economic structure is analyzed on the basis of the 9 criteria.

\subsection{Pace of Economic Growth and Per Capita Average Income}

\subsubsection{Pace of Economic Growth}

Growth in this period started from low to high, then conversely from high to low gradually and was kept on this repetition. (Figure 1)

The phase 1986-1995 indicated persistent growth, the following year was higher than the previous as it was the stage economy shifted from planned economy to multi-sector commodity economy; thus open-door policy begun to be performed and market signaled better for growth. Its peak was in the year of 1995 , up to $9,54 \%$.

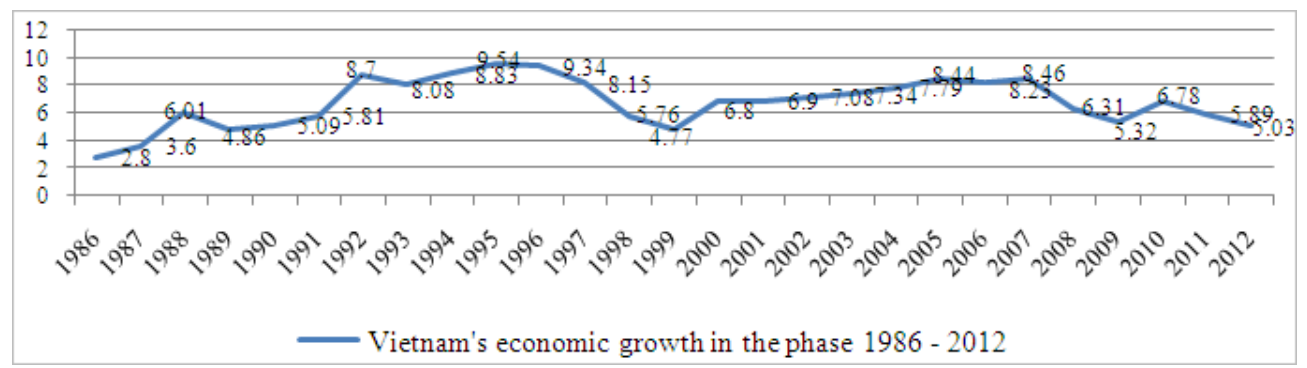

Source: [6, Page.70], [7]

Figure 1. Changes of Vietnam's economic growth in the phase 1986-2012.

- The phase 1996-1999 demonstrated the period of economic crisis, the year after was weaker than the year before. 1999 economic growth was $4.77 \%$ due to the joint influence of the 1997 monetary crisis, hitting Vietnam.

- The stage 2000-2007 showed that the growth was nearly the same as the earlier period 1986-1995. Again, growth of the following year was better than the previous, an increase from $6.8 \%$ in 2000 to $8.46 \%$ in 2007 . Financial markets, stock and real estate in Vietnam developed rapidly and State invested hugely in state-owned economic corporations through assistance and privileges of credits.

- The phase 2008-2012 was the beginning of economic recession. Growth speed fell steadily. It was $5.03 \%$ in 2012. This was the time of global financial crisis which has hit Vietnam's economy until the middle of 2013, and now there is no sign of growth recovery.

\subsubsection{Per Capita Average Income}

Vietnam's per capital average income raised from 86 USD per person in 1988 , to 357 USD per person in 1998, and 1,540 USD in 2012. (Figure 2)

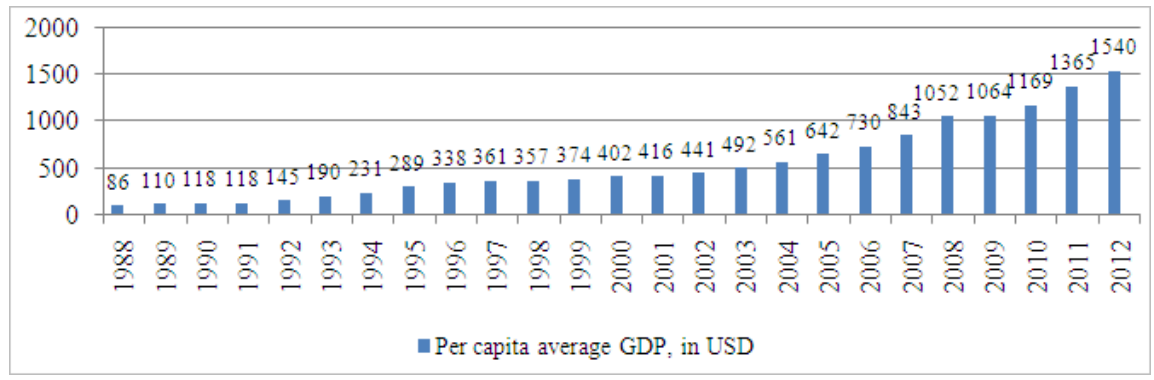

Source: [6; Page. 71], [8]

Figure 2. Vietnam per capita average income.

Table 1. Per capita average income in different groups of nations.

\begin{tabular}{lll}
\hline & Groups of nations & USD/person \\
\hline 1 & Low - income economics & $\leq 1,025$ \\
2 & Lower - middle - income economics & $1,026-4,035$ \\
3 & Upper - middle - income economics & $4,036-12,475$ \\
4 & High - income economics & $\geq 12,476$ USD \\
\hline
\end{tabular}

Source: [10]
Since per capita average income in 2008 reached 1,052 USD per person and exceeded 1,025 USD per person, Vietnam was out of the list of poor nations (low-income nations) but in the group of low-middle income. (Table 1)

After 24 years per capita average income went up 17.9fold. In the early 10 years, between 1988 and 1998, it increased 4,15fold; 10 years after (1998-2008) was 2,94fold and only 1,46fold from 2008 till 2012. Income rate fluctuated 
uncontrollably - rise and fall failed to comply to any rules, sometimes it raised rapidly then it fell sharply. (Figure 3)

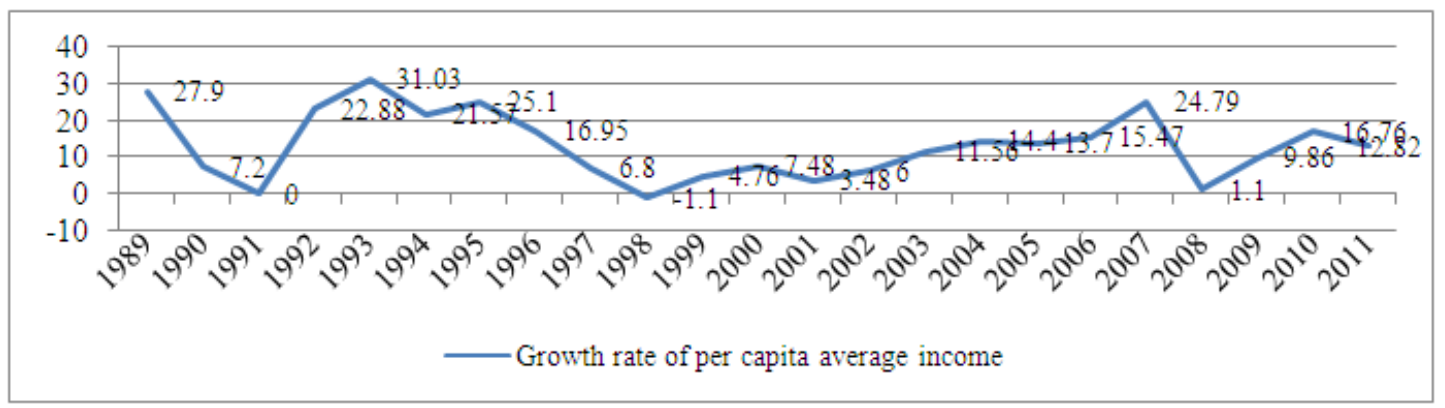

Source: Calculated by the author from [6; Page.71], [8]

Figure 3. Growth rate of per capita average income.

To escape from the lower-middle income group and be in the upper-middle group earning at least 4,036 USD per person, it is necessary for Vietnam that per capita average income be raised 2.62 fold, which is regarded as an uneasy mission and may take years to achieve with such the current economic growth.

\subsection{Economic Structure}

\subsubsection{Based on the Branches}

GDP structure (\%) based on the 3 branches: (1) Agriforestry - Fishery, (2) Industry - Construction, and (3) Service.
The phase 1986-1995 demonstrated the relatively visible shift of branch structure in the 2 branches, agriforestry fishery and service. An increase in percentage of agriforestryfishery in GDP was from $38.1 \%$ in 1986 to $40.49 \%$ in 1991 , and fell sharply by $27.43 \%$ in 1994 . Service raised from $33 \%$ in 1986 to $44 \%$ in 1995 . Industry and construction made up $28.90 \%$ in 1986 , and steadily fell by $22.67 \%$ in 1990 , then raised by $28.76 \%$ in 1995 , tantamount to the year of 1986 . That shift revealed that industry-construction transformed to the worse direction, following the logic of economic growth. (Figure 4)

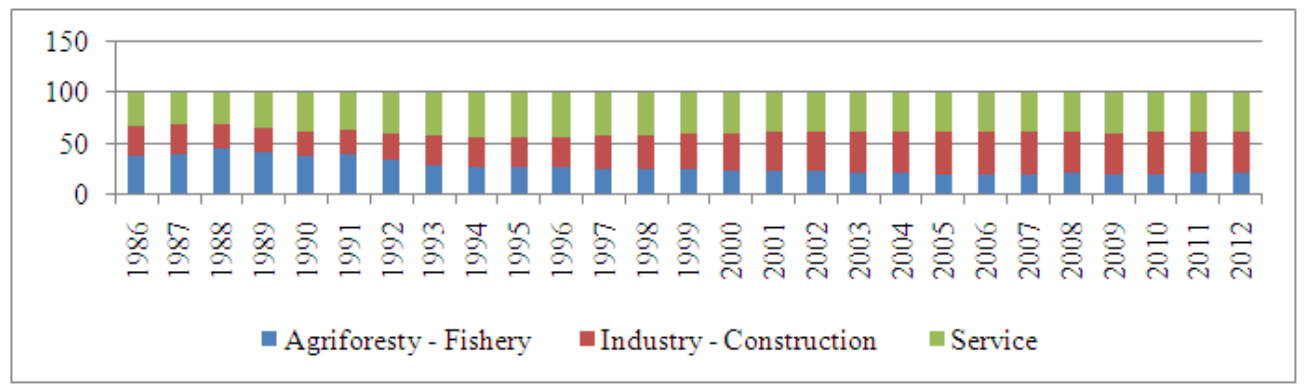

Source: [6; Page. 70], [7]

Figure 4. GDP structure (\%) based on branches.

In the phase 1995-2006, the structural shift was opposite toward the industry-construction and agriforestry-fishery. There was a positive modification of growing percentage of industry-construction and service $-29.73 \%$ in 1996 and a regular annual raise up to $41.54 \%$ in 2006 . At the same time percentage of agriforestry-fishery fell regularly from $27.76 \%$ in 1996 down to $20.40 \%$ in 2006. Service had a slight decrease and stood by the nearly same numbers in many years, from $42.51 \%$ in 1996 down to $38.06 \%$ in 2006 .

Structure of all branches in GDP in the time $2007-2012$ was seemingly stable (Figure 2.4) - no change took place, and economic model or economic structure was saturated.

\subsubsection{Based on Economic Sectors}

GDP structure (\%) based on economic sectors consists of 3 types: (1) State-owned economy, (2) Outer-state economy including team, private and individual, and (3) Foreign invested economy. Through the phase 1986-2012, all sectors were constant in structural shift in GDP, in the direction of a slight increase and decrease under the script that a raise of percentage in the foreign sector, a gradual fall in state sector, and a stability in outer-state sector. (Figure 5) 


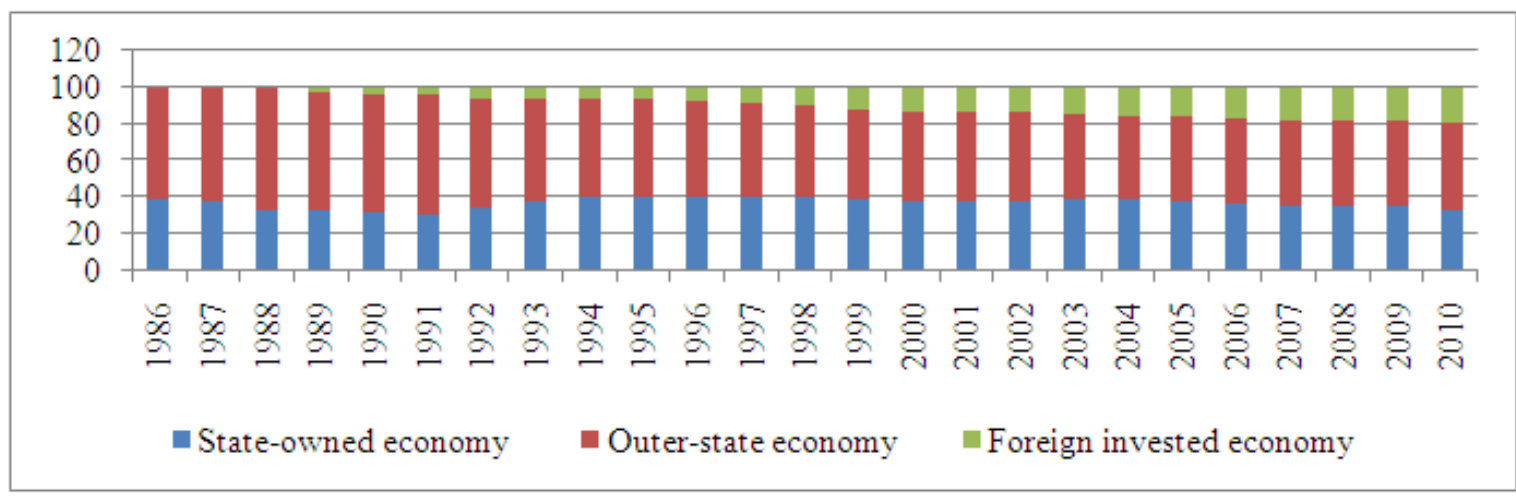

Source: [6; Page. 70]

Figure 5. GDP structure (\%) based on economic sectors.

The constancy of all economic sectors and branches during 15 years, between 1995 and 2010, indicated that it was the unconventional growth and economic development of a changing economy. As under the logic of growth applied for converting nations, this is the stage of powerful shift in outer state and foreign sectors; at the same time state sector falls lower to free market for competitive sectors. Construction and industry grow the fastest and make up an increasingly high percentage in all economic branches; then agriforestryfishery will sink more deeply to release resources to industry and service.

\subsection{Structure of goods trade and service}

\subsubsection{Structure of Goods Import-Export}

According to statistics, structure of trade in the phase 1985-1993 was nearly unchanging in both the goods import and export. The scale of goods export-import augmented slightly, higher next year, and increased rapidly in the phase 1994-2011. It made 2.985,2 million USD in 1993 and 4.054,3 in 1994, reaching $35.8 \%$ of import-export growth, opening up the time for growth of export. That went ahead the same with goods import.

Only in the single year of 1992 did trade surplus achieve 40 million USD during 1985-2011; the 25 remaining years all were trade deficit, later greater deficit; particularly the deficit of 2008 was the greatest 18.02 billion USD, 14.2 billion USD in 2007, 12.8 billion USD 2009, 12.6 billion USD 2010, and 9.8 billion USD 2011.

\subsubsection{Structure of Service Import-Export}

Vietnam' services have failed to compete with different nations, thus service import-export have existed in recent years, chiefly tourism and transportation service; others are inconsiderable. Conversely, Vietnam has geared more toward service import in transportation, insurance and finance.

Rate of trade deficit in goods and service was differential. It was maintained high but tended to fall in goods; it was increasingly greater in service though. (Figure 6)

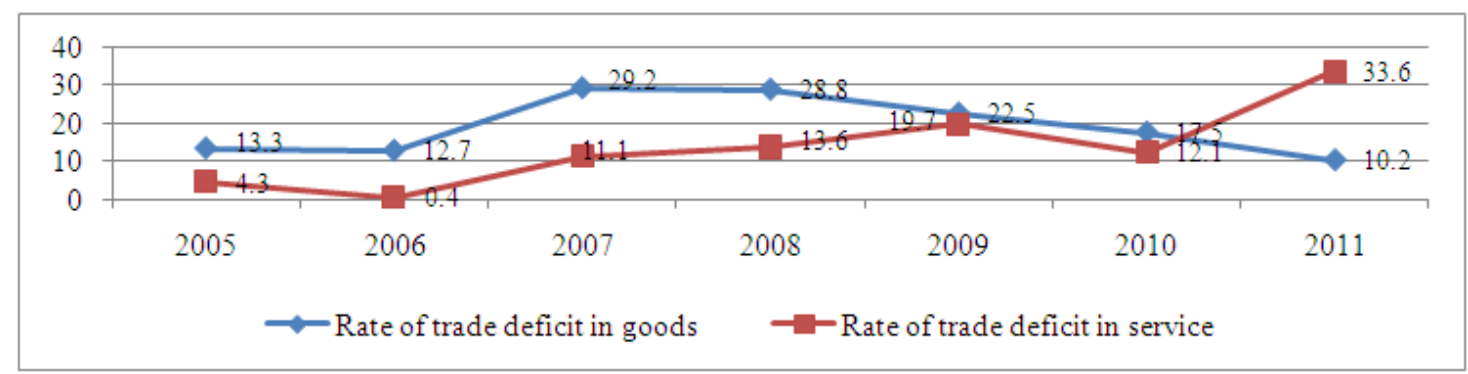

Source: [6; Page.80]

Figure 6. Rate of trade deficit (\%) in goods and service.

Trade deficit in service as tourism, transportation, finance and insurance, etc. will be keeping at high percentages in the following years, triggering a pressure on Vietnam's trade deficit and hitting trade balance and foreign exchange.

\subsection{Structure of Investment Capital}

\subsubsection{Investment Capital Divided into Economic Sectors}

Investment capital on average during each period of 5 years, as in the years 1996-2000, $2001-2005,2006-2010$ and the 2 years of 2010-2011 had a steady increase in the 3 economic sectors, in which capital of state sector was always the biggest, according to statistics. It was 64 thousand billion VND in 1996-2000 and 28.4 thousand billion VND for outerstate sector, and 25.5 for foreign invested sector, likewise the phases 2001-2005 and 2006-2010. It is proved that outerstate sector has not developed strongly enough to attract investment, and its capital has been used greatly. Rate of investment capital in comparison with GDP raised through time. 1996 - 2000 on the average was $33 \%$; 39.1\% during 


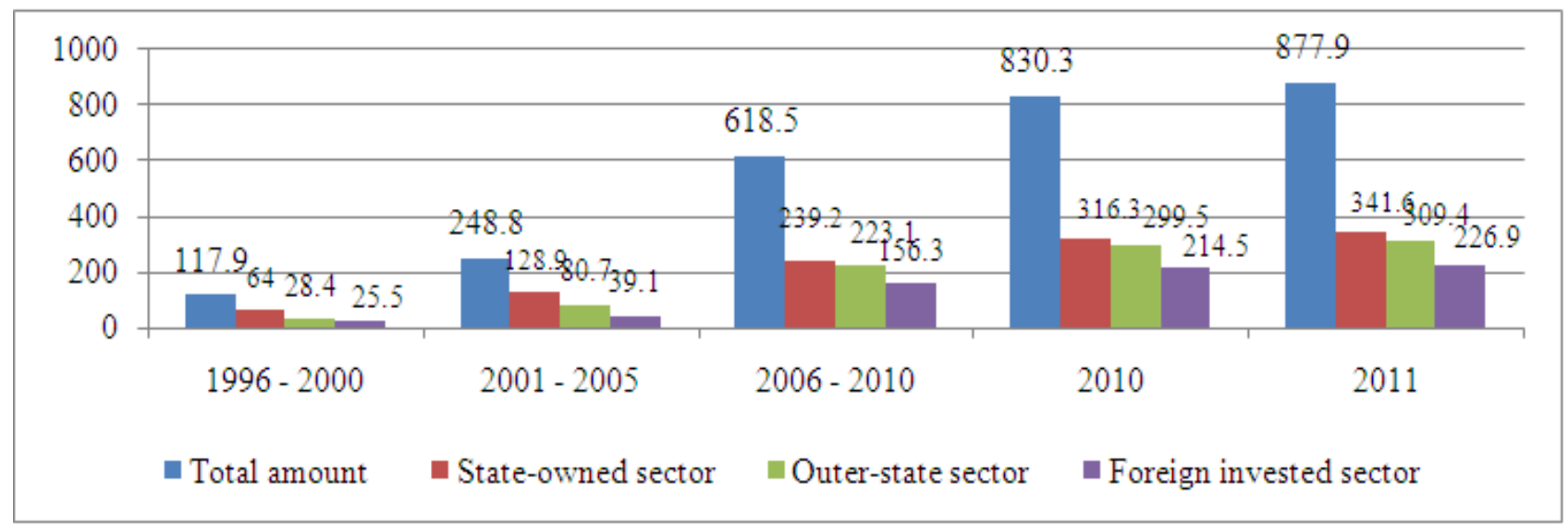

Source: [6; Page. 73]

Figure 7. Capital of growth investment.

\subsubsection{Investment Capital Based on Economic Branches}

The capital of manufacture has been lower than service which is invested the greatest, much more than agriforestryfishery and industry-construction. Capital for service was 3.7 fold higher in 1996-2000, 5.87fold 2001 - 2005, 8.1 fold 2006 - 2010, and 2010 8.54fold. Industry-construction were lower than service. Capital for it during 1996-2000 was merely 42.6 thousand billion, but 59.3 thousand billion for service, 105.2 thousand billion but 121.1 thousand billion compared with service in $2001-2005 ; 254.7$ but 324 during 2006 - 2010; in 2010 it was 312.1 thousand billion whereas service was up to 436.4 thousand billion. (Figure 8 )

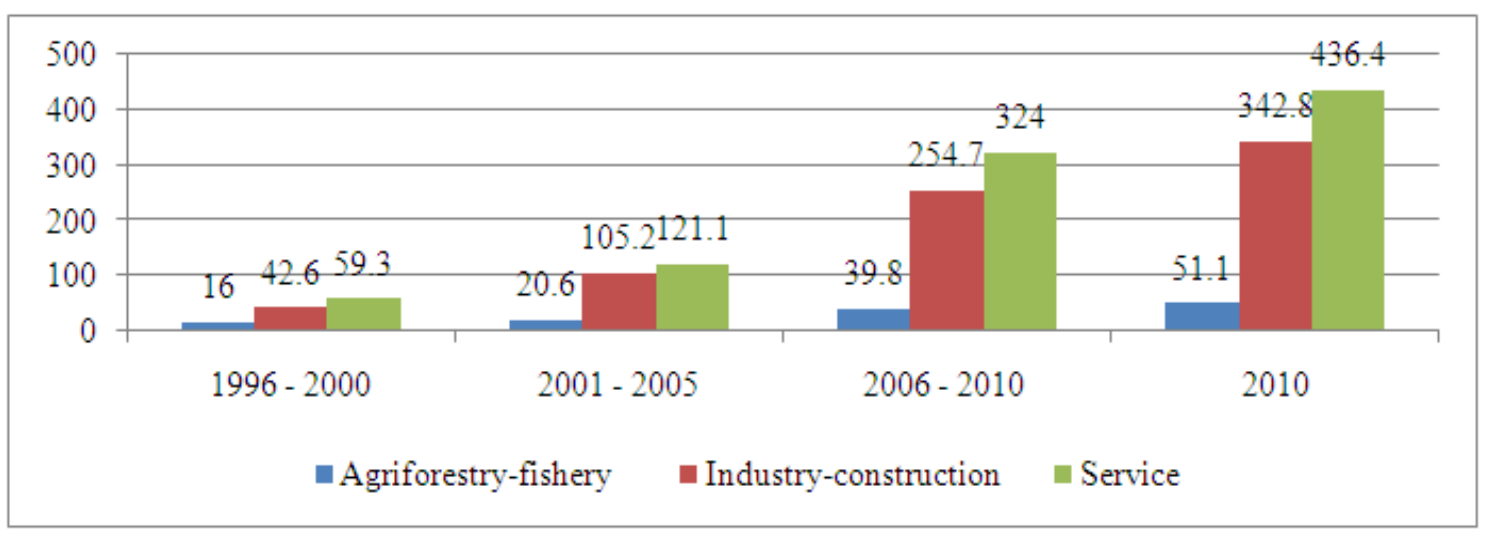

Source: [6; Page.73]

Figure 8. Investment Capital based on economic branches.

Investment capital between 1996 and 2010 led to a revelation that it was an irregularity when agriculture and industry was given a lower amount of capital than service, whereas Vietnam's economic background is in the group of low and lower-mid income nations, not in the group of developed countries.

Investment efficiency based on ICOR (calculated by the rate of investment capital/GDP divides pace of GDP growth (fold)) indicated that there was a gradual raise from 4.7 during 1996 - 2000, 5.2 during 2001 - 2005, and 6.1 during $2006-2010$. In 2010 it was 6.2 and 5.9 in 2011. Increasingly high ICOR showed a sign that using capital as a primary agent of growth failed to be as good as it was in the past. It unveiled that growth and economic development must steer toward the depth.

\subsection{Structure of State Finance}

\subsubsection{Structure of Budget Receipts and Expenditures (Rest)}

Based on the rest, structure of budget receipts and expenditures still ensured the balance of total incomings and outcomings. Total payments were always bigger than total receipts. An estimate in recent years, particularly in the phase of 2007-2009, indicated that rate of budget deficit went beyond the limit of 5\% GDP, in 2007 it was $7.3 \%$, $20085.2 \%$, and 2009 up to the highest $8.5 \%$. Additionally, rate of statebudget revenue compared with GDP drove higher and stood by $30 \%$. (Table 2). Source of budget income makes up a high percentage in GDP can help to balance budget and guarantee source of expenses, but it will be a 2-blade knife if it depends virtually on enterprises and citizens as it will kill economic motivation and drain the economy. 
Table 2. Receipts and Expenditures of state budget (rest) in the phase of 2005-2011.

\begin{tabular}{llllllll}
\hline Years & $\mathbf{2 0 0 5}$ & $\mathbf{2 0 0 6}$ & $\mathbf{2 0 0 7}$ & $\mathbf{2 0 0 8}$ & $\mathbf{2 0 0 9}$ & $\mathbf{2 0 1 0}$ & $\mathbf{2 0 1 1}$ \\
\hline (1).Total incomings & 228,287 & 279,472 & 315,915 & 416,783 & 442,340 & 559,370 & 674,600 \\
(2). Total outcomings & 262,697 & 308,058 & 399,402 & 494,600 & 584,695 & - & 796,000 \\
(3) Gap = (1) - (2) & $-34,410$ & $-28,586$ & $-83,487$ & $-77,817$ & $-142,355$ & - & $-121,400$ \\
(4). GDP in reality & 839,211 & 974,265 & $1,143,715$ & $1,485,038$ & $1,658,400$ & $1,980,914$ & $2,535,008$ \\
(5)Budget deficit compared with GDP = (3) - (4) & $-4.1 \%$ & $-2.9 \%$ & $-7.3 \%$ & $-5.2 \%$ & $-8.5 \%$ & - & $-4.7 \%$ \\
6. Rate of total incomings compared with GDP & $27.2 \%$ & $28.7 \%$ & $27.6 \%$ & $28.1 \%$ & $26.7 \%$ & $28.2 \%$ & $26.6 \%$ \\
\hline
\end{tabular}

Unit calculated: Thousand billion VND

Source: [6; Page. $72-73$ ]

\subsubsection{Structure of Public Debt and ODA}

Issues of public debt and its crisis have been the topic talked over globally since the 2008 world economic crisis. Both developed and growing nations have considered it with care for more strategic adaptation. Vietnam has been taken care of this matter by international community.

+ Scale of public debt: According to report from Economist magazine, Vietnam's public debt in 2010 was 50.935 billion USD, tantamount to $51.6 \%$ GDP. Though it was in the control (under 10\% GDP) and much lower than developed nations but higher than growing countries (from $30-40 \%$ GDP; China $17.4 \%$ and Indonesia $26.5 \%$ ). Vietnam's average rate of debt was estimated 0.8 billion USD (approximately 1.5 million billion VND), as equal as $49.5 \%$ GDP. The Vietnam's total debt until the end of 2011 was 1.392 million billion VND, as equal as 66.8 billion USD.

This rate based on per capita built up rapidly; 112 USD in 2001 and up to 580.91 USD in 2010 - a 5 fold increase during 10 years; and this rate in 2012 reached 790 USD per person.

+ Forms of borrowing: Public debt includes government debt, debt that government help to pay and debt of local authority, according to the 2009 law of public debt management. With this division, rate of debt of each until 2010 , in turn, was $44.3 \%$ GDP, $11.36 \%$ GDP and $0.94 \%$ GDP.

+ Domestic and exotic debt: FOREIGN debt plays an important role in the structure of Vietnam's public debt due to the greatest percentage. In 2010 , the total was $56.6 \%$ GDP public debt among which was $42.2 \%$ GDP of foreign debt and $14.4 \%$ GDP of home debt. Vietnam's supply source of foreign debt stems chiefly from ODA. In the list of the 2009 public debt list, debt from ODA made up $60.3 \%$ and $29.8 \%$ of debt from funding of home bonds. [9]

Though Vietnam's rate of public debt compared with GDP has been assessed to be at the safe level and on an average, but it tends to a gradual increase and may exceed the limit, leading to risks and beyond control, hence caution.

Official development supporting capital regarded as a necessity for growth investment will come really meaningful only when it is used efficiently for investment in infrastructure, otherwise it will stear to a bad outcome, leading to worse public debt.

\subsection{Fluctuation of Inflation, Gold and Foreign Exchange Rate}

Vietnam's consumer price index has kept at high rates. For example in the phase of 1986 - 1992 there was a great increase in price: $774.7 \%$ in $1986,222.1 \%$ in $1987,349.4 \%$ in 1988 and a steady fall by $67.1 \%$ in $1990,67.5 \%$ in 1991 and $17.5 \%$ in 1992. Afterwards, between 1992 and 1997, the index geared to a regular decrease by $3.6 \%$ in 1997 . The period of economic crisis and quick recovery between 1997 and 2003 pushed it to stand as high as $9.2 \%$ in 1997 quickly down to 0.1 in 1999 and -0.6 in 2000, then slightly augmented again under the economic improvement. The time of raise in goods from 2004 till 2012, especially from 20082012, economy and society suffered the pressure of price increase, triggering difficulties for people's lives. In 2007 was $12.63 \%$, in 2008 was $19.89 \%$ and stood by $11.75 \%$ in $2010,18.13 \%$ in 2011 and $9.21 \%$ in 2012. (Figure 9)

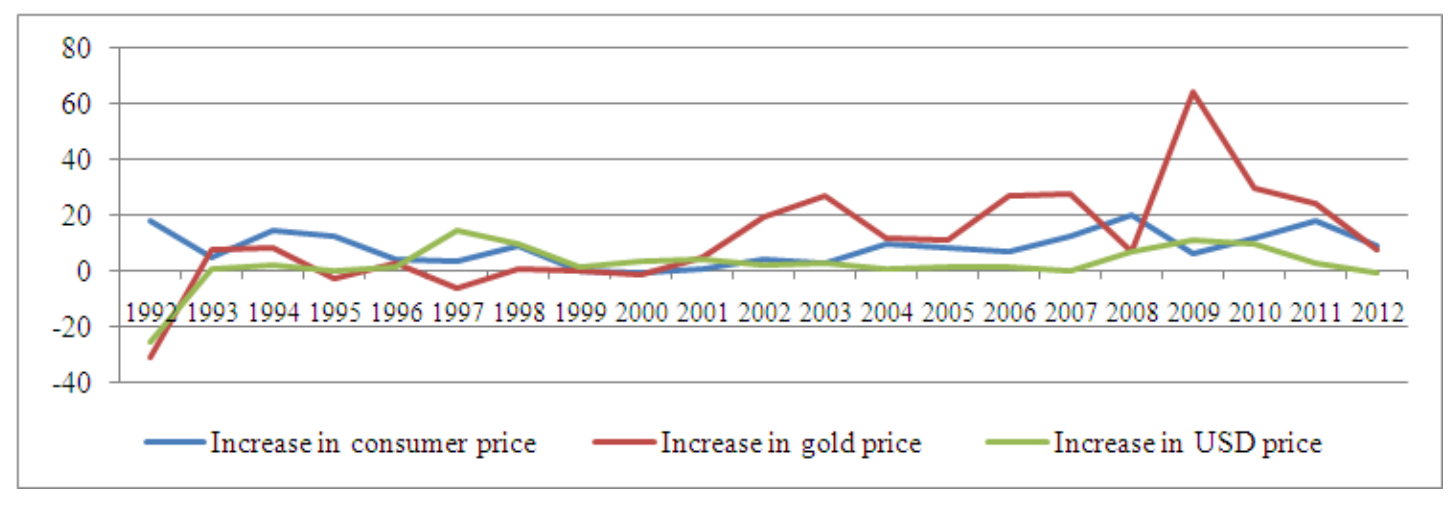

Source: [6], [7]

Figure 9. Rise and fall in consumer price, gold price and USD price. 
The high consumer price index and continual trade deficit have triggered pressure on exchange rate between USD and VND. Pace of increase in USD price has regularly raised and tended to be at high level in recent years. For instance, this speed in 2008 was $6.31 \%, 2009$ was $10.7 \%$, 2010 was $9.68 \%$ and 2011 was $2.24 \%$. That reflects the increasingly great devaluation of VND, bringing a few benefits for export but trouble for import and pushing consumer price higher and higher when economy is trade deficit and massive foreign currency is needed.

Home gold price has fluctuated enormously toward the world's price; in addition, the fact that economy has been ailing has produced a demand of buying and trading gold from people to earn interest, resulting in gold buying-andselling fever in the market in recent years, which has hardly benefited economy and society.

\subsection{Fluctuation of Bank Interest and Bad Debt of Bank System}

Operations of Vietnam's bank system throughout 20 years have developed vastly but potential of risks have existed, particularly credit activities with an abnormal increase in interest in the period of economic crisis and growing greater bad debt. High bank interest rate has exterminated enterprises' workings which are exceedingly thirsty for funds to maintain their operations.

\subsubsection{Chronology of Bank Interest}

Bank interest in the past 8 years $(2005-2013)$ : in 2005 popular mobilization rate swung 9\%. In 2006 all banks called more than $9 \%$. In 2007 over 10\%. In 2008 above $20 \%$. In 2009 , it stood by $9 \%$ due to government's assistance though policy of granting to make up for interest of demand stimulation. In 2010 interest was between 10\% and 17\% per year. In 2011 it fluctuated 14\%, and 9\% per year in 2012 .

\subsubsection{Bad debt in Bank System}

Bad debt has been having a negative effect on circulation of capital in economy, safety and efficiency of banks' business. Despite the different opinions of bad debt at commercial banks, it remains no satisfactory answer on rate of bad debt of these banks in Vietnam. Governor of stateowned banks claimed that this rate over the total of account outstanding at the banks was around $10 \%$, whereas stateowned bank inspection agency reported $8.6 \%$, as equal as 200,000 billion VND. Besides, Committee of national financial investigation stated $11.8 \%$, tantamount to 270,000 billion VND. The exact number how much it is stays a secret but it is said that bad debt at these banks is not small.

\subsection{Fluctuation of Private Enterprises: Establishment, Liquidation and Bankruptcy}

Establishment of private enterprises: The fact that law of enterprises issued in 1999 come into effect in 2000 and amended in 2005 boosted growth of private sector, resulting in shaping thousands of enterprises every year. The total of enterprises registering establishment and legally existing until Dec 31, 2012 in Vietnam were 622,977, according to report of Chamber of Vietnam commerce and industry (VCCI), and World Bank (WB) organized on March 14, 2013.

More than 160,000 private enterprises were founded in the period of time from 2000 till 2005, nearly 5fold of all established since 1990s. They created 3 million of new jobs and invested 323 thousand billion VND, higher than total of FDI in the same period.

In the phase of 2006-2010 there were 311,500 new enterprises, 2 fold in comparison with 5 years ago.

In the phase of 2010-2012: there were 540,000 new enterprises in 2010; 77, 548 in 2011 and 65,000 in 2012.

Enterprises winding up, going bankrupt and ceasing operation

In fact, business environment has been increasingly harder, and influences from global economy have had effects on all enterprises, not just in Vietnam. However, private businesses have become an impetus of the economy, particularly transitional economies as Vietnam. Dissolution, bankruptcy and failure in operation concerning numerous companies each year have made economy get sick social life of millions people have been in trouble.

At the late 2011, there were 622,977 enterprises in which 79,014 enterprises were wound up, according to an annual report of 2011Vietnamese enterprises talked by VCCI and WB on March 14. The number in 2010 was 43,137.

Among 79,014 firms were dispersed, there were 2,082 of private, 16,748 of limited liability companies with a single member, and 18,826 of limited companies with more than 2 members. Joint-stock companies reached the greatest number 41,357 , and the least was joint corporations with merely 1 firm.

In 2012, private sector continued to confront liquidation with estimated 55,000 enterprises ceasing operation.

\subsection{National Competitive Capacity}

Vietnam's got 4.1 scores compared with the maximum score of 7, ranking 75, according to report of the 2012-2013 global competitive capacity by WEF through a survey in 144 nations and regions.

Table 3. Ranking and Vietnam's GCI scores in the period of 2008-2012.

\begin{tabular}{llllll}
\hline Contents & $\mathbf{2 0 0 8}$ & $\mathbf{2 0 0 9}$ & $\mathbf{2 0 1 0}$ & $\mathbf{2 0 1 1}$ & $\mathbf{2 0 1 2}$ \\
\hline Scores (over 7) & 4.1 & 4.0 & 4.3 & 4.2 & 4.1 \\
$\begin{array}{l}\text { Ranks (/total } \\
\text { nations ranked) }\end{array}$ & $70 / 134$ & $75 / 133$ & $59 / 139$ & $65 / 142$ & $75 / 144$ \\
Rise/fall (+/-) & -2 & -5 & +16 & -6 & -10 \\
\hline
\end{tabular}

Source: [11]

It is obvious that Vietnam's rank improved only once, 4 years fell and made little progress during the last 5 years. 2012 score was the same as 2008 and the second as equal as 2009. Evaluation score and Vietnam's rank of competitive power have continually gone down since 2010 . Why has that happened is a question the answer of which is in the content 
inside of acomponent indicators constituting Vietnam's GCI.

\section{Structure of Industrial Products - A Ruler of Vietnam's Economic Structure}

Generally, shift in economic structure is often considered by economists to assess growth and economic development. It includes (i) branch (service, industry and agriculture), (ii) economic sectors (state, outer state and foreign invested sector), (iii) economic regions, etc. in the author's estimation, shift in economic structure has a little meaning to guide structure of industrial products - a crucial ruler to reflect growth capacity and form of economic structure.

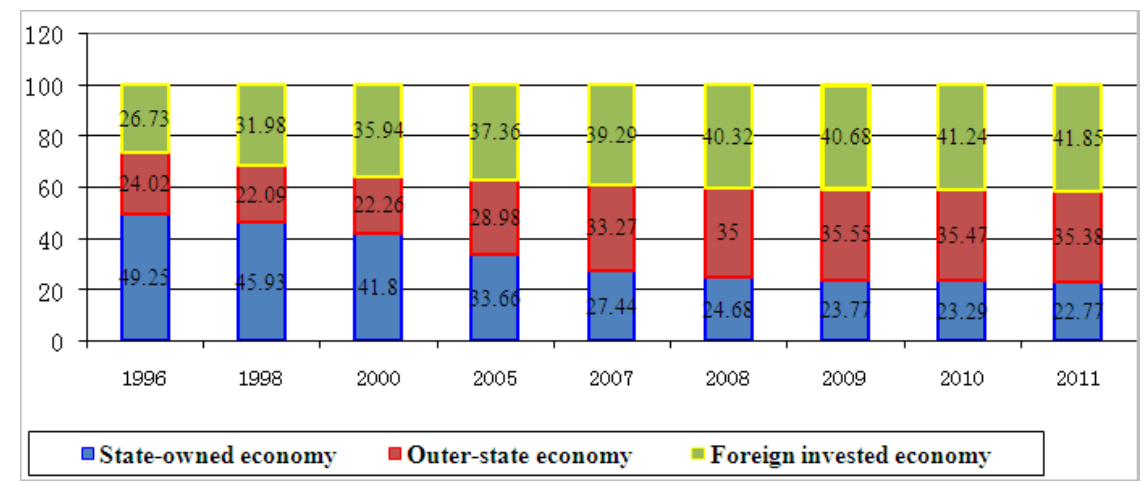

Source: [12]

Figure 10. Structure of industrial production value based on the 1994 's comparable price, in different economic sectors.

Figure 10 demonstrates the increasing participation of outer-state sector but the growing reduction of state sector, whereas foreign sector still made up a greater and greater percentage. The structure, on one hand, reflects the decrease in industrial value of home sectors, but the value acceleration of the economic sector with foreign invested capital. On the other hand, it reveals simply a trend of investment involvement in economy of all sectors but hardly reveals the quality of product, hence failure to disclose structure of industrial products (i) Foreign sector with a big percentage in industrial production unveils that they prevail in industry, but fails to state how good industrial products are, what type of products and how the using technology and where it ranks in the world. In fact, there are only $5-6 \%$ of nouvelle technology,
$80 \%$ of average tech, and $14-15 \%$ of outdated equipment, according to information from Ministry of Investment and Planning in the early 2013. (ii) The fact that there is an increase in percentage of outer state indicates people take part in industrial investment but once again it shows no product quality (iii) A decrease in state sector does not mean that the economy is of high competitiveness, but actually State let market regulate by itself as some of industrial products such as production of electricity, coal, natural resources and gas, ect are in the hand and controlled exclusively by state industrial corporations. Technology, management of assets, capital, and product quality are not mentioned yet.

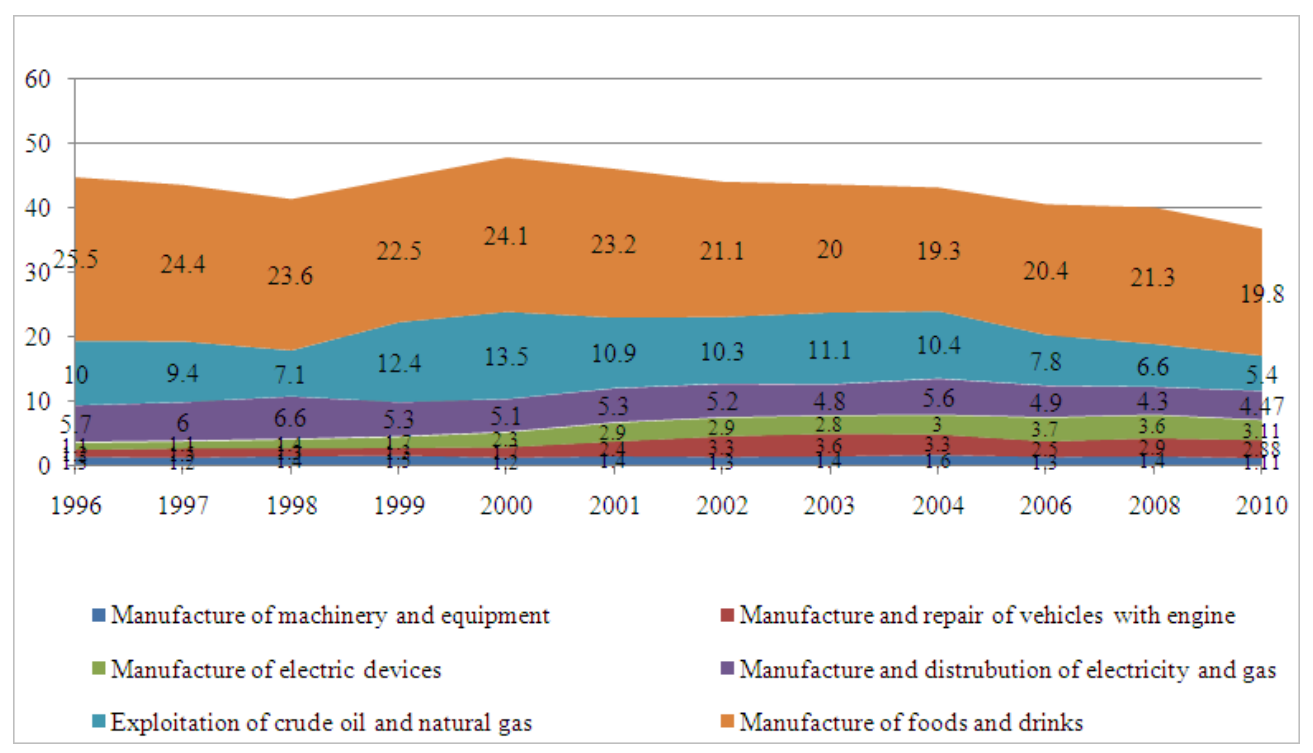

Source: [12]

Figure 11. Structure of industrial production based on real price, in industrial branches. 
The above structure indicates Vietnam industrial value during 15 years has primarily depended on natural resource exploitation including $10 \%$ of crude oil and natural gas. This number has steered to fall in recent years; the huge percentage of $20 \%$ is manufacture of foods and drinks. Actual industrial products have accounted for a small percentage - manufacture of machinery, devices $1.3 \%$, electric device $3 \%$, recycling products $0.1 \%$, manufacture and repair of vehicles and motors $2-3 \%$, manufacture of radios, television sets, communication devices $2.6 \%$ in 1996 $2000,1.9 \%$ in 2008, manufacture and distribution of electricity and gas 5\%. The picture of value structure of industrial production leads to the revelation that Vietnam's industry has been falling behind and making no improvements of both quality and quantity. Industrial products virtually rely on exploitation of crude natural resources, natural advantages of agricultural products and intensive-labor products. (Table 4)

Table 4. Dominant industrial products during 1995-2011.

\begin{tabular}{|c|c|c|c|c|c|c|}
\hline & Unit calculated & 1995 & 2000 & 2005 & 2010 & 2011 \\
\hline Clean coal & Thousand ton & 8350.0 & 11609.0 & 34093 & 44835 & 45824 \\
\hline Exploited crude oil & Thousand ton & 7620.0 & 16291.0 & 18519 & 15014 & 15180 \\
\hline Natural gas in form of gas & million $\mathrm{m}^{3}$ & & 1596 & 6440 & 9402 & 8480 \\
\hline Iron ore and pure iron ore & Thousand ton & & & 772.3 & 1972.1 & 2209.2 \\
\hline Copper ore and pure copper ore & Ton & & & 8001 & 49038 & 45007 \\
\hline Titan ore and pure titan ore & Thousand ton & & 134.5 & 404.9 & 586.8 & 554.5 \\
\hline Antimoan ore and pure antimoan ore & Ton & & & 333 & 608 & 717 \\
\hline Exploited rock & Thousand $\mathrm{m}^{3}$ & 10657 & 22169 & 70836 & 146857 & 152203 \\
\hline Sand in all types & Thousand $\mathrm{m}^{3}$ & & & 63114 & 60161 & 56513 \\
\hline Gravel, pebble & Thousand $\mathrm{m}^{3}$ & 14363 & 33273 & 3329.5 & 2883.6 & 2783.5 \\
\hline Apatit ore & Thousand ton & & 785.0 & 1024.2 & 2324.5 & 2563.2 \\
\hline Sea salt & Thousand ton & 689.0 & 590.0 & 897.7 & 975.3 & 928.9 \\
\hline Canned meat & Ton & & & 3191.0 & 4677 & 4596.2 \\
\hline Canned seafood & Ton & & 7.4 & 37.5 & 76.9 & 82.5 \\
\hline Frozen seafood & Thousand ton & & 177.7 & 681.7 & 1278.3 & 1399.1 \\
\hline Fishsauce & Million liters & 149.0 & 167.1 & 191.5 & 257.1 & 277.2 \\
\hline Canned vegetable & Thousand ton & & & 16.9 & 48.4 & 50.8 \\
\hline Canned fruits and seeds & Thousand ton & 12.8 & 11.4 & 55.9 & 60.1 & 60.1 \\
\hline Refined vegetable oil & Thousand ton & 38.6 & 280.1 & 397.2 & 565.9 & 571.2 \\
\hline Fresh milk & Million liters & & & 215.7 & 520.6 & 640.3 \\
\hline Milk powder & Thousand ton & & & 49.1 & 58.9 & 75.7 \\
\hline Husked rice & Thousand ton & 15582 & 22225 & 28429 & 33473 & 34040 \\
\hline Refined sugar & Thousand ton & 93.0 & 790.3 & 1102.3 & 1141.5 & 1204 \\
\hline Coffee powder and soluble coffee & Thousand ton & & & 24.3 & 68.1 & 67.4 \\
\hline Processed tea & Thousand ton & 24.2 & 70.1 & 127.2 & 211.0 & 216.2 \\
\hline Monosodium glutamate & Thousand ton & 65.0 & 454.4 & 244.7 & 248.2 & 261.1 \\
\hline Foods for cattle and poultry & Thousand ton & & & 4752.2 & 8708.8 & 9266 \\
\hline Foods for aquatic products & Thousand ton & & & 748.8 & 2096 & 2194.9 \\
\hline Brandy and white wine & Million liters & 51.4 & 124.2 & 221.1 & 349.4 & 322.6 \\
\hline Beer & Million liters & 465.0 & 779.1 & 1460.6 & 2420.2 & 2650.6 \\
\hline Mineral water & Million liters & & 150.8 & 247.2 & 458.5 & 499.2 \\
\hline Pure water & Million liters & & 27.9 & 328.3 & 1342.9 & 1288.5 \\
\hline Tobaco & Million sacks & 2147.0 & 2835.8 & 4484.7 & 5073.9 & 5454.9 \\
\hline Fibre & Thousand ton & 59.2 & 129.9 & 259.2 & 1176.9 & 1294.8 \\
\hline Fabric & Million $\mathrm{m}^{2}$ & 263.0 & 356.4 & 560.8 & 2604.5 & 2890.9 \\
\hline Garments & Million pieces & & & 1156.4 & 2604.5 & 2890.9 \\
\hline Leather shoes and slippers & Million pairs & 46.4 & 107.9 & 218.0 & 50.3 & 52.8 \\
\hline Fabric shoes & Million pairs & 22.2 & 32.4 & 34.2 & 347.0 & 381.8 \\
\hline Sneakers & Million pairs & & 109.219 & 240.79 & 347 & 381.8 \\
\hline Sawn timber & Thousand $\mathrm{m}^{3}$ & 1606 & 1744 & 3232 & 5236.7 & 5125.6 \\
\hline Paper and board & Thousand ton & 216.0 & 408.5 & 901.2 & 1536.8 & 1593.9 \\
\hline Newspapers and other printed products & Billion pages & 97 & 184.662 & 450.309 & 716.2 & 676.4 \\
\hline Gold phosphate & Thousand ton & & & 3961 & & \\
\hline Chemical fertilizer & Thousand ton & 931.0 & 1209.5 & 2189.5 & 2411.3 & 2396.8 \\
\hline NPK fertilizer & Ton & & & 2083.5 & 2645.4 & 2895.4 \\
\hline Pesticide & Ton & 15566 & 20948 & 45877 & 73633 & 74160 \\
\hline Herbicide & Ton & & & 21120 & 24218 & 23959 \\
\hline Shampoo and conditioning & Ton & & & 55536 & 49280 & 51631 \\
\hline Toothpaste & Ton & & & 30907 & 30307 & 36082 \\
\hline Milk bath and facial foam & Ton & & & 6099 & 14328 & 18503 \\
\hline Detergent and products of washing and bleaching & Thousand ton & & & 573 & 815.6 & 763.5 \\
\hline Inflatable tyre of automobiles and tractors & Thousand pieces & & & 1708 & 5494 & 5300 \\
\hline Inflatable tyre of motorbikes and bicycles & Thousand pieces & & & 37465 & 48526 & 44397 \\
\hline
\end{tabular}




\begin{tabular}{|c|c|c|c|c|c|c|}
\hline & Unit calculated & 1995 & 2000 & 2005 & 2010 & 2011 \\
\hline Tube used for cars and airplanes & Thousand pieces & & & 9483 & 7872 & 7990 \\
\hline Tube used for motorbikes and bicycle & Thousand pieces & & & 57692 & 92782 & 86645 \\
\hline Plastic packing & Thousand ton & & 39.4 & 278.8 & 662.9 & 713.4 \\
\hline Civilian china & Million pieces & 187.0 & 247.1 & 513.6 & 351.3 & 373 \\
\hline Sanitation china & Thousand pieces & & 1525 & 4573 & 7295 & 7739 \\
\hline Refined brick & million pieces & 6892 & 9087 & 16530 & 20196 & 20328 \\
\hline Refined tile & Million pieces & 561.0 & 366.2 & 526.6 & 587.4 & 630 \\
\hline Cement & Thousand ton & 5828 & 13298 & 30808 & 55801 & 58994 \\
\hline Casted bars of iron and steel and other crude forms & Thousand ton & 1862 & 1803 & 473.5 & 2434 & 2354 \\
\hline Laminated steel and shaped steel & Thousand ton & 470 & 1583 & 3403 & 7910 & 7528 \\
\hline Printing machines & Thousand pieces & & & 672.5 & 14561.9 & 15907.1 \\
\hline Telephones & Thousand pieces & & & 168.6 & 9405.7 & 10906.2 \\
\hline Mobile phones & Thousand pieces & & & & 37497.2 & 78323 \\
\hline Television sets & Thousand pieces & 770.0 & 1013.1 & 2515.3 & 2800.3 & 3219.4 \\
\hline Digital cameras & Thousand pieces & & & & 3273 & 1307.7 \\
\hline Standard batteries $(1,5 \mathrm{~V})$ & million bars & 138.0 & 128.6 & 395.7 & 397 & 405.4 \\
\hline Accumulators in all types & Thousand kwh & & & 8308 & 15931 & 16543 \\
\hline Electric light bulbs & Million pieces & 25 & 70 & 102.2 & 350.4 & 395.4 \\
\hline Refrigerators and home freezers & Thousand pieces & & 174.5 & 692.6 & 1540.9 & 1204.1 \\
\hline Home washing machines & Thousand pieces & & 159 & 336.6 & 467.4 & 679.9 \\
\hline Home electric fans & Thousand pieces & 369.2 & 328.4 & 1751.7 & 7174.1 & 7244.4 \\
\hline Air conditioners & Thousand pieces & & 52.5 & 147.9 & 343.7 & 350.8 \\
\hline Machine of plucking rice of the ears & Thousand pieces & 36.398 & 18.938 & 26.5 & 9 & 9.2 \\
\hline Assembled automobiles & Thousand pieces & 4 & 13.547 & 59.2 & 112.3 & 107.9 \\
\hline Assembled motorbikes & Thousand pieces & 62.0 & 463.4 & 1982.1 & 3506.6 & 4208.5 \\
\hline Bicycles & Thousand pieces & 236.0 & 659 & 2524.5 & 705.9 & 717 \\
\hline Generated electricity & Million kwh & 14665.0 & 26683 & 52078 & 91722 & 101309 \\
\hline Tap-water as commodity & Million $\mathrm{m}^{3}$ & & & 933 & 1416.8 & 1517.1 \\
\hline
\end{tabular}

Source: [13]

Vietnamese industrial products are mainly natural resources exploitation, rudimentary processing and exploitation from nature, or products using old technology; virtually there are no products of high tech and heavy industry.

State's investment in the period of 1995-2012 demonstrated that state sector took priority over the remaining 2 sectors but its products such as natural resources exploitation, food and drinks manufacture, textiles, etc were seemingly in the vicious circle and the same as the others. (Figure 12). That leads to an evaluation that this sector has failed to play a key role in making industrial breakthroughs to gear the economy to sustainable growth.

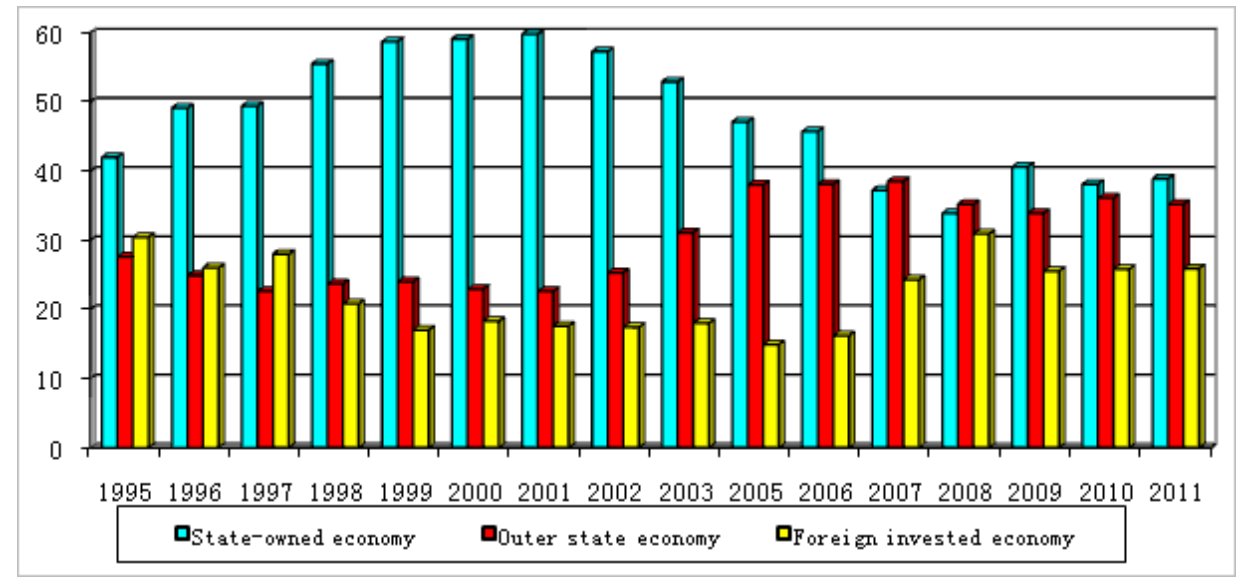

Source: [14]

Figure 12. structure of investment capital in economic sectors.

Foreign invested sector has been expected to break through for industrial growth, increase in income, improvement of living standards for laborers and for social-economic development; it has contributed inconsiderately to Vietnamese industry though. The transfer pricing ${ }^{1}$ of thousands of enterprises in the past few years has triggered budget deficit and disagreement from tax management authority and public.

In the list of industrial-product value in the phase 19952012, some points about foreign investors' industrial investment should be paid attention: (i) Exploitation of gas resources, natural gas, and manufacture of wooden products 
will be draining quickly the national natural resources, paying a high price on long-term consequences concerning environment, flood, and red mud disasters (ii) Production of food and beverage, textiles and leather uses primarily a vast number of laborers with low prices, has no long-run effect on growth of industry, economy and engineering, makes no improvement for laborers' lives as well. (iii) There are few products of metal manufacture, machinery and industrial devices and motors. It is visible that foreign investors have been exploiting and benefiting from the defects of Vietnamese economy as outmoded engineering, cheap laborers, crude resources that have not been protected strictly by regulations on environment, conditions of exploitation and social responsibility.

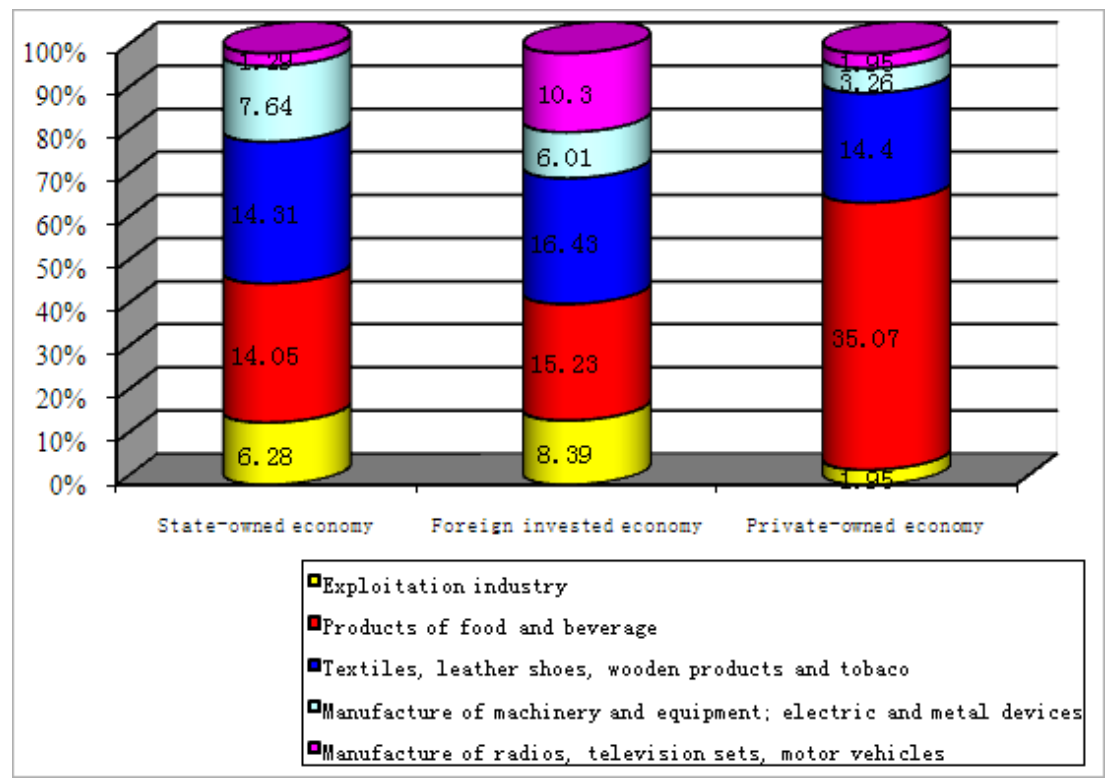

Source: Calculated by the author based on 2010 General Office, Industry

Figure 13. Structure of industrial value of all economic sectors in 200.

Figure 13 unveils that the rather blur role of all sectors in manufacture of industrial products serving industrial growth, agriculture and consumer industrial products. All of them virtually pay more attention to foods and beverage, textiles, leather shoes, wooden products, whereas products of metal, machinery and devices are low in value.

\section{Conclusion and Suggested Measures}

Economic structure is affected decisively by structure of industrial product. Its transformation is believed to stem from change in production structure, the core of which is industrial-products structure.

Theoretical matters in connection with economic take-off and transformation of economic structure in all parts of the world in modern times as Rostow, Hollis B. Chenery, Kuznets, contain core factors in take-off and national competitiveness related to industrial structure, particularly products of basic industry and heavy industry. They suport the hypothesis of industrial-products structure as a measurement tool of economic structure to stand on firm scientific grounds.

The comprehensive picture of Vietnam's economic structure analyzed on the basis on 9 criteria leads to the revelation that it is relatively unsustainable, triggering challenges and a vicious circle concerning reduction in growth, low per capita income, trade deficit, inflation, and VND devaluation. Moreover, public and bank finance are shakable, increasingly weak private-owned sector, and a rise in bankruptcy. Such big problems easily make economy get hurt and hard for sustainable development and take-off.

Suggested measures: It is vital that Vietnam's industrial products structure concentrate on heavy industry, supporting industry, consuming industry and processing industry of advantageous products. It is necessary that position and role of each sector be determined for restructuring and development. Main conflicts should be double-checked and adjusted such as law of bids, preferential credits, tax and quota. In addition, models of research institutes of engineering development, industrial and high-tech zones, and industrial cities need national overall plans along with typical policy issued on time. And finally, attraction of Vietnamese intelligence at home and abroad is supposed to suit requirements in modern time.

\section{References}

[1] Van Schalkwyk, 2011 http://www.wiki.answers.com/Q/What_is_economic_structure

[2] Geoff Riley, 2011. UK Manufacturing Output, http://www.tutor2u.net/blog/index.php/site/author/3/

[3] Lawonline,

2013.

Restructure, http://cdu.summon.serialssolutions.com/search?s.fvf $\% 5 B \% 5 \mathrm{D}$ $=\& s . q=$ restructure \&spellcheck $=$ true $\&$ s.fvf $\% 5 \mathrm{~B} \% 5 \mathrm{D}=$ Content Type $\% 2$ CBook+Review\%2Ctrue\&keep_r=true 
[4] http://www. en.wikipedia.org/wiki/Restructuring

[5] Nguyen Tan Phat, 2011. Identification of Vietnamese economic structure on the basis of analysis of industrialproduct structure, Economic Research, (393), February, 2011)

[6] Vietnamese Economics Magazine, 2012. Economy in 2011 and 2012 Vietnam and the World

[7] Vietnamese General Statistics Office, 2013. Economy and Society in 2012, http://www.gso.gov.vn/default.aspx?tabid=413\&thangtk=12/2 012

[8] Phuong Mai - Khanh Linh, 2012. Macroeconomics Investment, http://cafef.vn/kinh-te-vi-mo-dau-tu/gdp-vietnam-nam-2012-uoc-dat-136-ty-usd-thu-nhap-binh-quan-daunguoi-dat-1540-usd-20121203042658795ca33.chn

[9] Le Thi Dieu Thao and Nguyen Thao Phuong, 2011. Vienam's public debt - Matters for further discussion, http://www.sbv.gov.vn/wps/wcm/connect/69765a004794f5438 798d78a2a12afeb/le+phan+thi+dieu+thao.pdf?MOD=AJPER ES\&CACHEID $=69765 \mathrm{a} 004794 f 5438798 \mathrm{~d} 78 \mathrm{a} 2 \mathrm{a} 12 \mathrm{afeb}$
[10] World Bank, 2013. Data, Country and Lending Groups, http://data.worldbank.org/about/countryclassifications/country-and-lending-Groups\#Low_income

[11] World Economics Forum, 2013. The Global Competitiveness Report 2012-2013 of WEF

[12] General Statistics Office, 2013. Industry, value of industrial production based on 1994 comparable price, divided into economic sectors, http://www.gso.gov.vn/default.aspx?tabid=391\&idmid=3\&Ite $\mathrm{mID}=13236$

[13] General Statistics Office, 2013. Industry, chief industrial products, http://www.gso.gov.vn/default.aspx?tabid=391\&idmid=3\&Ite $\mathrm{mID}=13225$

[14] General Statistics Office, 2013. Investment and Construction, investment capital based on economic sector, http://www.gso.gov.vn/default.aspx?tabid=392\&idmid=3\&Ite $\mathrm{mID}=13107$ 